\title{
On farm Phenotypic Characterization of Indigenous Goat Breeds within Their Production System in Ancher and Gemechis Districts, West Hararghe Zone, Eastern Ethiopia
}

\author{
Mohammed Yousuf ${ }^{1,}$,, Tesfaye Getachew ${ }^{2}$, Elias Bayou ${ }^{1}$ \\ ${ }^{1}$ Department of Animal Science, Faculty of Agriculture, Mizan Tepi University, Mizan Teferi, Ethiopia \\ ${ }^{2}$ International Center for Agricultural Research in the Dry Areas (ICARDA), Addis Ababa, Ethiopia
}

Email address:

mahammedyousuf1@gmail.com (M. Yousuf), tesfayegecho@yahoo.com (T. Getachew), eliasbayou2009@yahoo.com (E. Bayou)

${ }^{*}$ Corresponding author

To cite this article:

Mohammed Yousuf, Tesfaye Getachew, Elias Bayou. On farm Phenotypic Characterization of Indigenous Goat Breeds within Their Production System in Ancher and Gemechis Districts, West Hararghe Zone, Eastern Ethiopia. American Journal of Life Sciences. Vol. 9, No. 2, 2021, pp. 25-35. doi: 10.11648/j.ajls.20210902.12

Received: February 26, 2021; Accepted: April 21, 2021; Published: May 8, 2021

\begin{abstract}
This study was conducted to study the morphological characteristics of indigenous goats breed under farmer's management condition in Ancher and Gemechis districts, West Hararghe Zone, Eastern Ethiopia. The most frequently observed coat color pattern of goat was $(60.8 \%)$ plain, $(9.1 \%)$ spotted and $(30.1 \%)$ were patchy coat color and coat color type in the study area was brown (36.8\%) followed by white $(24.7 \%)$. Heart girth had consistently the highest correlation coefficient $(0.80),(0.76),(0.90)$ with body weight of intact male, female and castrated male goat respectively in both study districts. The mean of body weight, body length, chest girth, wither height, chest width, pelvic width, face length, horn length, rump length, ear length intact male are $38.1 \pm 0.7,65.2 \pm 0.63,74.0 \pm 0.70,69.0 \pm 0.48,15.0 \pm 0.12,15 . \pm 0.14,19.8 \pm 0.18,16.0 \pm 0.56,16.0 \pm 0.23$, $14.4 \pm 0.14$, respectively. The corresponding values for the female goat were $32.0 \pm 0.22,62.0 \pm 0.20,70.0 \pm 0.22,64.7 \pm 0.15$, $14.2 \pm 0.04,13.8 \pm 0.04,19.0 \pm 0.06,12.0 \pm 0.23,15.0 \pm 0.07,14.1 \pm 0.04$, respectively. The mean of body weight, body length, chest girth, wither height, chest width, pelvic width, face length, horn length, rump length, ear length castrated male are $44.4 \pm 0.42$, $69.6 \pm 0.37,78.9 \pm 0.42,72.9 \pm 0.29,15.1 \pm 0.07,16.4 \pm 0.08,20.5 \pm 0.12,18.1 \pm 0.44,15.8 \pm 0.14,14.7 \pm 0.08$, respectively. The body weight of castrated male goat was higher than the intact male and female goat in both districts. As conclusion castrated male goat has potential for improving income and to increase economy of smallholder farmers in the study areas as well as in the surrounding areas.
\end{abstract}

Keywords: Breeding Objective, Breeding Practice, Selection Criteria

\section{Introduction}

Agriculture in Ethiopia is the backbone of the country's economy and livestock is an integral part of agriculture. Ethiopia have large livestock population; comprising 59.5 million cattle, 30.70 million sheep, 30.20 million goats, 8.44 million donkeys, 2.16 million horses, 1.21 million camels, 0.41 million mules and 56.53 million poultry [11] and endowed with diverse and abundance livestock species [14]. It is eminent that livestock products and by-products in the form of meat, milk, honey, eggs, cheese, and butter supply provide the needed animal protein that contributes to the improvement of the nutritional status of the people.
Livestock also plays an important role in providing export commodities, such as live animals, hides and skins to earn foreign exchanges to the country [11]. In developing regions, populations of livestock of the same species, especially if they are geographically isolated and recognized by ethnic owners as being distinct from others around them, are traditionally recognized/considered as distinct eco-types or breeds [29]. The nomadic communities rear most of the goat and sheep. The genetic improvement of livestock involves identification of the breeds or strains of livestock reared in the country and also the type of environment in which they are reared, this involves the description of the breed, moreover, successful livestock improvement programs 
involves the compatibility of the genotypes with those of the breeding objectives of the rearers and the production systems [20].

The small ruminants are preferred by the smallholder farmers from the fact that they require small investments; have shorter production cycles, faster growth rates and greater environmental adaptability as compared to large ruminants [30]. They provide their owners with a vast range of products and services. They contribute to landless, rural farming, peri-urban and increasingly to urban households by providing food, income, manure and clothing [24]. According to these authors, they also make important indirect contributions to households with crop by-products, integration with other farming enterprises, and in the social, cultural and religious aspects of every-day life. In addition to these, there are no banking facilities in rural areas and an easy way to store cash for future needs are through the purchase of small ruminants [22]. Goats are browsers and are selective feeders and thus it enables them to thrive on sparse bushes and shrubs they also have broad feeding habits and short reproductive cycle, which provide goats with comparative advantage over other species [19]. It important for diversifying agriculture and livestock production, creating employment opportunities, improving family income, building capital, contributing to human nutrition and reducing risk like those of vagaries of nature, in addition to their quantifiable outputs of several products [13]. Goats are reared under diverse agro-ecological zones from arid to cold and over in a wide range of production systems. Goats in particular are an under-utilized and poorly understood livestock resource especially in the developing countries, an interest in goat production in the tropics has grown over the years. Rearing of small ruminants play important socio economic role in many rural areas where they are reared for generating income and as bank on hooves [6].

There are approximately 570 breeds and types of goats in the world, of which 89 are found in Africa [16]. The goat population of Ethiopia ranks high both in Africa and in the world. According to recent estimates, the goat population in the country is about 30.20 million. Out of these total goats, 70.61 percent are females and about 29.39 percent are males (CSA 2017). With respect to breed, almost all of the goats are indigenous which accounts for $99.99 \%$ [11]. In Ethiopia, goats kept in different parts of the country for the purpose of food source, income generation, socio-cultural wealth and source of other valuable non-food products used as raw materials for various traditional household products manufactured in local cottage industries. Goats in the lowlands of the country kept both for milk and meat production, whereas in the highlands they are mainly kept for meat and income generation [5].

Despite the wide distribution and large size of the Ethiopian goat population, the productivity per unit of animal and the contribution of this sector to the national economy is relatively low. This may be due to different factors such as poor nutrition, prevalence of diseases, and lack of appropriate breeding strategies and poor understanding of the production system as a whole [31]. Therefore, characterization of the production systems and the available genetic resources is necessary to design improvement programs in the future. However, until now, there is limited information about the phenotypic characteristics of the indigenous goat breed and nothing has been done to characterize, identify and document the characterization of the existing indigenous goat breed in Ancher and Gemechis districts. Thus characterizations of these goats' resources in these areas help as prerequisite for conservation, documentation, utilization and to design breeding program for sustainable development. Therefore, in this study, phenotypic characterization carried out to describe qualitative and quantitative traits of indigenous goats breed in Ancher and Gemechis districts. The objective of this study was to describe on farm phenotypic characteristics of indigenous goat breeds within their production system and to develop equation for prediction of body weight of goat by using linear body measurements.

\section{Materials and Methods}

\subsection{Description of the Study Area}

The study was conducted in Ancher and Gemechis districts, Eastern Ethiopia. Ancher is located $9^{0} 0^{\prime}$ North Latitude and $40^{\circ} 0^{\prime}$ 'East Latitude and $8^{\circ} 30^{\prime}$ North Latitude and $40^{\circ} 25^{\prime}$ East Latitude. It is capital town, Cheleleka, is located at a distance of $75 \mathrm{~km}$ from the city of Metahara town and is found at a distance of 265 kilometers from Addis Ababa. District extends between 960-3220 meters above sea level. With regard to land feature, $85 \%$ is mainly rolling while forest exists in 8 of the kebeles. The total land area $898.09 \mathrm{~km} 2 / 85,809$ hek. Geographically, Ancher district is characterized by spatial variation of topographic features ranging from plain to undulating plateaus marked with a series of valleys. Ancher district is classified into highland, midland, and lowland agro-climatic zones, covering about $13 \%, 24 \%$ and $63 \% \%$ of the total area of the district, respectively. The district receives an average mean annual rain fall and temperature ranging between $900-1200 \mathrm{~mm}$ and $07^{0} \mathrm{c}-38^{0} \mathrm{c}$, respectively, manly the district rain fall pattern is bi-modal. Gemechis is located at $343 \mathrm{~km}$ east of Addis Ababa and about $17 \mathrm{~km}$ south of Chiro, capital town of the zone. It shares borders with Chiro district in the west and north, Oda Bultum district in the south and Mesala district in the east. The district is found within 1300 to 2400 meters above sea level (m.a.s.l). It receives an average annual rainfall of $850 \mathrm{~mm}$. The district has bi-modal distribution in nature with small rains starting from March/April to May and the main rainy season extending from June to September/October. The average temperature is $20{ }^{0} \mathrm{C}$. Farming system of the area is a subsistence crop growing and livestock rearing type.

\subsection{Site Selection and Sampling Techniques}

The sampling technique employed for this study was purposive sampling technique, which was based on based on 
the potential of goat production in the zone. West Hararghe has 14 districts from which two districts mainly Ancher and Gemechis were selected purposively based on the distribution of goat population. A survey visit was made in advanced together with local staff of office of agriculture they are familiarized with the range of agro ecological conditions, the existing farming systems and goat population in the study area. Meeting was held with local farmers and every opportunity was taken for wayside informal discussion. Discussions were also held with zonal and district agricultural experts as well as development agents to gather information about the distribution of West Hararghe Zone in the selected two districts. Three Rural kebeles which represent different agro-ecology were selected purposively based on the potential and distribution of goat from each of the two districts. So Cheleleka, Didin and Carora kebeles selected from Ancher district and Kune, Dingate and KaseHija kebeles selected from Gemechis district. Secondary information on the distribution, number and type of goat were obtained from agricultural offices of the respective district before the actual field work.

\subsection{Data Type and Method of Data Collection}

Data quantitative (body measurements) and qualitative (morphological characters) were collected from sampled goats in the study areas. The qualitative data were collected and recorded using visual assessment of individual animals in the field, where as quantitative data were collected based on field measurements. Before data collection, selected goat owners were clearly briefed about the importance of the study. They were also asked permission and their willingness to participate before any task of the study was commenced.

Quantitative and qualitative traits data collection

The standard breed descriptor lists developed for goat by FAO (2012) were closely followed in selecting morphological variables. During a single visit to sampling site qualitative and quantitative measurements were made on 870 matured goat of both sex (435 per district or 145 per rural kebeles) based FAO guideline indicated that 100 to 300 mature females and about 30 mature males per population are required for phenotypic characterization indicated and the standard breed descriptor list for the goats developed by [FAO, 2012] was closely followed to record both qualitative observation and quantitative measurements. Quantitative traits including; body length, chest girth, chest width, wither height, pelvic width, face length, horn length, rump length, ear length and scrotum circumference were measured using measuring tape, while live body weight was measured using suspended spring balance having $100 \mathrm{~kg}$ capacity. All the measurements were made in the morning body before the animals left for grazing and after restraining and holding the animals in an unforced position. Pregnant does and sick goats were purposely excluded from measurements to avoid measurement biases. The measurement was made on animal that are classified based on sex, district and age group. Animal age classifications were made using dentition technique supplemented with owner information. Adult goats were classified in to four age group; 1PPI (one pair permanent incisor), 2PPI (two pair permanent incisor), 3PPI (three pair permanent incisor), 4PPI (four pair permanent incisor) based on the description of African goat (Wilson and Durkin 1984). Quantitative traits observed were coat color pattern, coat color type, head profile, horn, horn shape, horn orientation, ear orientation, wattle, ruff, bread were observed and recorded.

\subsection{Data Management and Statistical Analysis}

\subsubsection{Morphological and Body Measurement Data}

Observations on qualitative traits were analyzed for male and female goats using frequency procedure of Statistical Analysis System [27]. Chi-square test was employed when required to test the independence of categories or to test association between categorical variables. Quantitative traits (Body weight and other body measurements) were analyzed using the General Linear Model procedure (PROC GLM) procedures of the Statistical Analysis System [27]. For adult animals; sex, district and age group of the goat were fitted as independent variables while body weight and linear body measurements except scrotum circumference were fitted as dependent variables. Scrotum circumference was analyzed for intact male by fitting age group and district as fixed factor. Least square means with their corresponding standard errors were calculated for each body trait of different sex, dentition, district and dentition by sex interaction. When analysis of variance declares significance, least square means were separated using Tukey-Kramer test.

Model to analyze adult body weight and other linear body measurements except for scrotum circumference was

$$
\mathrm{Yijk}=\mu+\mathrm{Ai}+\mathrm{Sj}+\mathrm{D} k+\mathrm{A} i * \mathrm{~S} j+\text { eijk }
$$

Where: Yijk=the observed $l$ (body weight or LBMs) in the $i$ th age group, $j$ th sex and $k$ th district,

$\mu=$ overall mean,

A $i=$ the effect of $i$ th age group ( $i=1,2,3$ and 4) PPI,

$\mathrm{S} j=$ the effect of $j$ th $\operatorname{sex}(\mathrm{j}=$ female or male $)$,

$\mathrm{D} k=$ the effect of $k t \mathrm{~h}$ district ( $k=$ Ancher and Gemechis),

$\mathrm{A} i * \mathrm{~S} j=$ age by sex interaction and eijk=random residual error

Model used to analyze scrotal circumference (SC) are: $Y i k=\mu$ $+\mathrm{A} i+\mathrm{D} k+\mathrm{e} i j$

Where: Yik=the observed $l(\mathrm{SC})$ in the $i$ th age group and $k$ th district,

$\mu=$ overall mean, $\mathrm{A} i=$ the effect of $i$ th age group $(i=1,2$, 3 and 4) PPI,

$\mathrm{D} k=$ the effect of $k$ th district ( $k=$ Ancher and Gemechis), eikl=random residual error.

\subsubsection{Correlation and Regression Analysis}

Pair wise correlation analysis among different quantitative variables was employed using PROC CORR of SAS. Parameter considered for male goat live body weight and other body measurements including: body length (BL), chest girth (HG), chest width $(\mathrm{CW})$, wither height $(\mathrm{WH})$, pelvic width 
(PW), face length (FL), horn length (HL), rump length, ear length (EL) and scrotum circumference (SC) were considered, whereas scrotum circumference (SC) will be avoided for the analysis of female goats and castrate male. A pair wise correlation was computed for each of sex classes. Stepwise regression was employed using PROC REG of SAS to regress body weight on body measurements. Best fitting models will be selected based on coefficient of determination $\left(R^{2}\right)$, mean square error (MSE), the Mallows C Parameters C (p), Alkaike's Information Criteria (AIC) and Schwarz Bayesian Criteria (SBC). The following model was used for the prediction of body weight from body linear measurements.

For intact male:

$$
\begin{gathered}
\mathrm{Y} j=\alpha+\beta 1 X 1+\beta 2 X 2+\beta 3 X 3+\beta 4 X 4+\beta 5 X 5+\beta 6 X 6 \\
+\beta 7 X 7+\mathrm{ej}
\end{gathered}
$$

Where: $Y j=$ the response variable; body weight

$\alpha=$ the intercept $X 1, X 2, X 3, X 4, X 5, X 6$ and $X 7$ are the explanatory variables body length, chest girth, wither height, chest width, pelvic width, face length, horn length, rump length, ear length, scrotal circumference respectively. $\beta 1$, $\beta 2 \ldots \beta 7$ is regression coefficient of the variables $X 1, X 2 \ldots X 7$, $e \mathrm{j}=$ the residual random error.

For female and castrated male:

$Y j=\alpha+\beta 1 X 1+\beta 2 X 2+\beta 3 X 3+\beta 4 X 4+\beta 5 X 5+\beta 6 X 6+$ ej

Where: $Y j=$ the dependent variable body weight

$\mathrm{A}=$ the intercept $X 1, X 2, X 3, X 4, X 5$ and $X 6$ are the independent variables; body length, chest girth, wither height, chest width, pelvic width, face length, horn length, rump length, ear length, respectively. $\beta 1, \quad \beta 2 \ldots \beta 6$ is regression coefficient of the variable $X 1, X 2 \ldots X 6$, ej=the residual random error.

\section{Result and Discussion}

\subsection{Characterization of Physical Traits}

The frequency and their percentage of qualitative traits of goat population in Ancher and Gemechis districts for both male and female are presented in Table 1. Out of the total sampled goat population in the study area 870 goats $(60.8 \%)$ plain, (9.1\%) spotted and (30.1\%) were patchy coat color. The overall dominant coat color type in the study area was brown $(36.8 \%)$ followed by white $(24.7 \%)$. The sampled indigenous goat population in the study districts had straight head profile $(69.6 \%$ and $64.2 \%)$, concaves $(12.2 \%$ and $17.5 \%)$, and convex (18.1\% and $18.3 \%$ ) for male and female, respectively. The majority of goats in the study area had no wattles $(79.6 \%$ and $90.2 \%)$ for male and female goats, respectively. Among sampled goat population in the study area $88.5 \%$ of males had ruff and $100 \%$ of females had no ruff. However, higher when contrast with the report of (Alefe $2014)$ in Shabelle zone who reported that $(8.23 \%)$ male goat had ruff. About $82.5 \%$ and $82.5 \%$ of the goat population in the study area had beard for male and had not beard for female, respectively. Most (53\%) of sampled goat population in the study area had horn. Out of the total goats had horn, $(64.8 \%$ and $60.5 \%)$ had straight, (12\% and $25.7 \%)$ had curved, $(23.2 \%$ and $13.8 \%)$ had spiral horn shape for male and female, respectively. Regarding horn orientation, oblique upward $(22.5 \%$ and $37.9 \%)$, back ward $(77.5 \%$ and $62.1 \%)$ and polled $(47.4 \%$ and $46.8 \%)$ for male and female, respectively. The current study result was disagreement with the report of (Alefe 2014) conducted in Shabelle zone (Gode, Denan, Adadle districts) was (99.48\%) had horn presence. The most dominant ear orientation were carried horizontally $(60.2 \%)$ followed by semi-pendulous $(25.7 \%)$. Erect $(7.8 \%)$ and pendulous $(6.2 \%)$ were observed in the goat population. The chi-square test for assumption of equal proportion of categorical variables in two (Ancher and Gemechis) sample goat population indicated that among the variables considered in this study coat pattern, coat color type, head profile, horn presence, horn shape, ear orientation, and beard were found to significantly $(\mathrm{p}<0.05)$ differ between districts while ruff, horn orientation and wattle were not significantly ( $>0.05$ ) affected by district.

\begin{tabular}{|c|c|c|c|c|c|c|c|c|c|c|}
\hline \multirow{3}{*}{ Character Attributes } & \multicolumn{8}{|c|}{ District (N \%) } & \multirow[t]{2}{*}{ Overall } & \multirow{3}{*}{$\mathbf{X}^{2}$} \\
\hline & \multicolumn{3}{|c|}{ Ancher } & \multicolumn{5}{|l|}{ Gemechis } & & \\
\hline & Male & Female & Total & Male & Female & Total & Male & Female & Total & \\
\hline Coat color pattern & & & & & & & & & & 9.41 \\
\hline Plain & $85(63)$ & $187(62.3)$ & 62.5 & $91(67.4)$ & $166(55.3)$ & 59.1 & $176(65.2)$ & $353(58.8)$ & $529(60.80)$ & \\
\hline Patchy & $40(29.6)$ & $74(24.7)$ & 26.2 & $35(25.9)$ & $113(37.7)$ & 34 & $75(27.8)$ & $187(31.2)$ & $262(30.1)$ & \\
\hline Spotty & $10(7.4)$ & 399 (13) & 11.3 & $9(6.7)$ & $21(7)$ & 6.9 & $19(7)$ & $60(10)$ & $79(9.1)$ & \\
\hline Coat color type & & & & & & & & & & 33.48 \\
\hline White & $20(14.8)$ & $53(17.7)$ & 19.3 & $35(25.9)$ & $107(35.7)$ & 32.6 & $55(20.4)$ & $160(26.7)$ & $215(24.7)$ & \\
\hline Black & $3(2.2)$ & $14(4.7)$ & 3.9 & $5(3.7)$ & $20(6.7)$ & 5.7 & $8(3)$ & $34(5.7)$ & $42(4.8)$ & \\
\hline White black & $19(14.1)$ & $50(16.7)$ & 15.9 & $10(7.4)$ & $45(15)$ & 12.6 & $29(10.7)$ & $95(15.8)$ & $124(14.3)$ & \\
\hline White red & $23(17)$ & $51(17)$ & 14.5 & $15(11.1)$ & $45(15)$ & 13.8 & $38(14.1)$ & $96(16)$ & $134(15.4)$ & \\
\hline Grey & $5(3.7)$ & $15(5)$ & 4.6 & $5(3.7)$ & $10(3.3)$ & 3.4 & $10(3.7)$ & $25(4.2)$ & $35(4)$ & \\
\hline Brown & $65(48.1)$ & 117 (39) & 41.8 & $65(48.1)$ & $73(24.3)$ & 31.7 & $130(41.8)$ & $190(31.7)$ & $320(36.8)$ & \\
\hline Head profile & & & & & & & & & & 12.74 \\
\hline Straight & $90(66.7)$ & $192(64)$ & 64.8 & $98(72.6)$ & $193(64.3)$ & 66.9 & $188(69.6)$ & $385(64.2)$ & $573(65.9)$ & \\
\hline Concave & $19(14.1)$ & $37(12.3)$ & 12.9 & $14(10.4)$ & $68(22.7)$ & 18.9 & $33(12.2)$ & $105(17.5)$ & 138 (15.9) & \\
\hline Convex & $26(19.3)$ & $71(23.7)$ & 22.3 & $23(17)$ & $39(13)$ & 14.3 & $49(18.1)$ & $110(18.3)$ & $159(18.3)$ & \\
\hline Horn presence & & & & & & & & & & 94.36 \\
\hline
\end{tabular}

Table 1. Description of qualitative traits of goats in Ancher and Gemechis districts 


\begin{tabular}{|c|c|c|c|c|c|c|c|c|c|c|}
\hline \multirow{3}{*}{ Character Attributes } & \multicolumn{8}{|c|}{ District (N \%) } & \multirow[t]{2}{*}{ Overall } & \multirow{3}{*}{$\mathbf{X}^{2}$} \\
\hline & \multicolumn{3}{|c|}{ Ancher } & \multicolumn{5}{|l|}{ Gemechis } & & \\
\hline & Male & Female & Total & Male & Female & Total & Male & Female & Total & \\
\hline Presence & $95(70.4)$ & 207 (69) & 69.4 & $47(34.8)$ & $112(37.3)$ & 36.6 & $142(52.6)$ & $319(53.2)$ & $461(53)$ & \multirow{6}{*}{7.74} \\
\hline Polled & $40(29.6)$ & $93(31)$ & 30.6 & $88(65.2)$ & $188(62.7)$ & 63.4 & $128(47.4)$ & $281(46.8)$ & 409 (47) & \\
\hline Horn shape & & & & & & & & & & \\
\hline Straight & 70 (73.7) & $129(62.3)$ & 65.9 & $22(46.8)$ & $64(57.1)$ & 54.1 & $92(64.8)$ & $193(60.5)$ & $285(61.8)$ & \\
\hline Curved & $4(4.2)$ & $50(24.2)$ & 17.9 & $13(27.7)$ & $32(28.6)$ & 28.3 & $17(12)$ & $82(25.7)$ & $99(21.5)$ & \\
\hline Spiral & $21(22.1)$ & $28(13.5)$ & 16.2 & $12(25.5)$ & $16(14.3)$ & 17.6 & $33(23.2)$ & $44(13.8)$ & $77(16.7)$ & \\
\hline
\end{tabular}

Table 1. (Continued)

\begin{tabular}{|c|c|c|c|c|c|c|c|c|c|c|}
\hline \multirow{3}{*}{$\begin{array}{l}\text { Character } \\
\text { Attributes }\end{array}$} & \multicolumn{8}{|c|}{ District (N \%) } & \multirow[t]{2}{*}{ Overall } & \multirow{3}{*}{$X^{2}$} \\
\hline & \multicolumn{3}{|c|}{ Ancher } & \multicolumn{5}{|l|}{ Gemechis } & & \\
\hline & Male & Female & Total & Male & Female & Total & Male & Female & Total & \\
\hline Horn orientation & & & & & & & & & & 2.61 \\
\hline Oblique upward & $22(23.2)$ & $86(41.5)$ & 35.8 & $10(21.3)$ & $35(31.2)$ & 28.3 & $32(22.5)$ & $121(37.9)$ & $153(33.2)$ & \\
\hline Backward & $73(76.8)$ & $121(58.5)$ & 64.2 & $37(78.7)$ & $77(68.8)$ & 71.7 & $110(77.5)$ & $198(62.1)$ & $308(66.8)$ & \\
\hline Ear orientation & & & & & & & & & & 22.31 \\
\hline Erect & $3(2.2)$ & $15(5)$ & 4.1 & $21(15.6)$ & $29(9.7)$ & 11.5 & $24(8.9)$ & $44(7.3)$ & $68(7.8)$ & \\
\hline Pendulous & $7(5.2)$ & $24(8)$ & 7.1 & $9(6.7)$ & $14(4.7)$ & 5.3 & $16(5.9)$ & $38(6.3)$ & $54(6.2)$ & \\
\hline Semi-pendulus & $48(35.6)$ & $82(27.3)$ & 29.9 & $29(21.5)$ & $65(21.7)$ & 21.6 & $77(28.5)$ & $147(24.5)$ & $224(25.7)$ & \\
\hline $\begin{array}{l}\text { Carried } \\
\text { horizontally }\end{array}$ & $77(57)$ & $179(59.7)$ & 58.9 & $76(56.3)$ & $192(64)$ & 61.6 & $153(56.7)$ & 371 (61.8) & $524(60.2)$ & \\
\hline Wattle & & & & & & & & & & 2.0 \\
\hline Presence & $23(17)$ & $27(9)$ & 11.5 & $32(23.7)$ & $32(10.7)$ & 14.7 & $55(20.4)$ & $59(9.8)$ & $114(13.1)$ & \\
\hline Absence & $112(83)$ & $273(91)$ & 88.5 & $103(76.3)$ & $268(89.3)$ & 85.3 & $215(79.6)$ & $541(90.2)$ & $756(86.9)$ & \\
\hline Ruff & & & & & & & & & & 0.37 \\
\hline Presence & $124(91.9)$ & $0(0)$ & 28.5 & $115(85.2)$ & $0(0)$ & 26.4 & $239(88.5)$ & $0(0)$ & $239(27.5)$ & \\
\hline Absence & $11(8.1)$ & $300(100)$ & 71.5 & $20(14.8)$ & $300(100)$ & 73.6 & $31(11.5)$ & $300(100)$ & $631(72.5)$ & \\
\hline Beard & & & & & & & & & & 6.71 \\
\hline Presence & $114(84.4)$ & $68(22.7)$ & 41.8 & $108(80)$ & $37(12.3)$ & 33.3 & $222(82.2)$ & $105(17.5)$ & 327 (37.6) & \\
\hline Absence & $21(15.6)$ & $232(77.3)$ & 58.2 & $27(20)$ & $263(87.7)$ & 66.7 & $48(17.8)$ & $495(82.5)$ & $543(62.4)$ & \\
\hline
\end{tabular}

$\mathrm{N}=$ number of goat population exhibiting a quantitative character, $\mathrm{X}^{2}=$ Person Chi-square

\subsection{Correlation Between Body Weight and Linear Body Measurements}

Table 2. Correlation coefficients among body measurements and weight of females and intact males of indigenous goats in the study area (values above the diagonal are for females and below the diagonal are for males) ( $N=120$ intact male; $N=600$ females)

\begin{tabular}{|c|c|c|c|c|c|c|c|c|c|c|}
\hline & BW & BL & CG & WH & $\mathrm{CW}$ & PW & FL & HL & RL & EL \\
\hline BW & 1 & $0.75^{*}$ & $0.76^{*}$ & $0.63 *$ & $0.48^{*}$ & $0.62 *$ & $0.47 *$ & $0.41 *$ & $0.30 *$ & $0.29 *$ \\
\hline BL & $0.75^{*}$ & 1 & $071 *$ & $0.63 *$ & $0.47 *$ & $0.61 *$ & $0.50 *$ & $0.45^{*}$ & $0.28 *$ & $0.24 *$ \\
\hline CG & $0.80 *$ & $0.67 *$ & 1 & $0.59 *$ & $0.40 *$ & $0.56^{*}$ & $0.50 *$ & $0.54 *$ & $0.29 *$ & $0.22 *$ \\
\hline WH & $0.69 *$ & $0.63 *$ & $0.63 *$ & 1 & $0.37 *$ & $0.53 *$ & $0.46^{*}$ & $0.44 *$ & $0.23 *$ & $0.23 *$ \\
\hline $\mathrm{CW}$ & $0.52 *$ & $0.53 *$ & $0.34 *$ & $0.39 *$ & 1 & $0.49 *$ & $0.34 *$ & $0.27^{*}$ & $0.21 *$ & $0.19 *$ \\
\hline PW & $0.69 *$ & $0.62 *$ & $0.63 *$ & $0.68 *$ & $0.47 *$ & 1 & $0.49 *$ & $0.39 *$ & $0.25 *$ & $0.17 *$ \\
\hline FL & $0.43 *$ & $0.35^{*}$ & $0.38 *$ & $0.29 *$ & $0.39 *$ & $0.36^{*}$ & 1 & $0.38 *$ & $0.26^{*}$ & $0.16^{*}$ \\
\hline $\mathrm{RL}$ & $0.43^{*}$ & $0.45^{*}$ & $0.51 *$ & $0.39^{*}$ & $0.44^{*}$ & $0.39 *$ & $0.32 *$ & $0.04 \mathrm{~ns}$ & 1 & $0.02 \mathrm{~ns}$ \\
\hline EL & $0.42 *$ & $0.26^{*}$ & $0.32 *$ & $0.13 \mathrm{~ns}$ & $0.21 *$ & $0.14 \mathrm{~ns}$ & $0.15 \mathrm{~ns}$ & $0.24 \mathrm{~ns}$ & $0.24 *$ & 1 \\
\hline $\mathrm{SC}$ & $0.39 *$ & $0.29 *$ & $0.32 *$ & $0.33^{*}$ & $0.29 *$ & $0.34 *$ & $0.17 *$ & $0.26^{*}$ & $0.24 *$ & $0.11 \mathrm{~ns}$ \\
\hline
\end{tabular}

$\mathrm{BW}=$ Body weight, $\mathrm{BL}=$ Body length, $\mathrm{CG}=$ Chest girth, $\mathrm{HW}=$ Height at whither; $\mathrm{CW}=$ chest width; $\mathrm{PW}=\mathrm{Pelvic}$ width, $\mathrm{FL}=$ face length, $\mathrm{HL}=$ horn length $\mathrm{RL}=$ Rump length; $\mathrm{EL}=$ Ear length; $\mathrm{SC}=\mathrm{Scrotal}$ circumference, ${ }^{*}$ Correlation is significant at the $P<0.05$, ns $=\mathrm{Correlation}$ is not significant at the $P<0.05$, $\mathrm{N}=$ number of animals.

The Pearson coefficient of correlation among various body measurements of goats in the study area are presented in Tables 2. Positive and highly significant $(p<0.05)$ were observed between body weight and linear body measurements for both male and female of indigenous goats considered in the study area. The quantitative traits in both male and female indigenous goat population, body weight was indicated that highly correlated with chest girth, body length, wither height and pelvic width $0.76,0.75,0.63$ and
0.62 in female of indigenous goat population, respectively and chest girth, body length, wither height and pelvic width $0.80,0.75,0.69$ and 0.69 in male of indigenous goat population, respectively. However, moderate correlations were observed between chest width, face length, horn length, rump length, ear length and scrotal circumference 0.52, 0.43, $0.33,0.43,0.42$ and 0.39 for male goat population, respectively and chest width, face length, horn length, rump length and ear length $0.48,0.470 .41,0.30$ and 0.29 for 
female goat population, respectively.

Coefficients of correlation between body weight and studied traits in this study varied from highly strong $(0.90)$ to very weak $(0.17)$ and highly significant $(P<0.05)$ to nonsignificant (Table 3 ). The correlation between LBM and body weight was higher in castrated male than intact male. This variation may be explained due to the difference in fat deposition variation between castrated male and intact male goats and due to highly management for castrated male goat than intact male goat. Chest girths have high correlation for castrated male and intact male. Similar with the report of [21] among measured linear quantitative variables chest girth $(\mathrm{r}=0.769)$ up to $(0.98)$ was the highest positively associated variable with body weight both for male and female Abergelle and Central Highland goat breeds. Also agreement with the report of [17] reported that from all quantitative traits in both male and female Begait goat population, body weight was indicated that highly correlated with heart girth $(\mathrm{r}=0.96)$ in male Begait goats and $(0.89)$ in female Begait goats.

Table 3. Correlation coefficients among body measurements and weight of castrate males and intact males of indigenous goats in the study area (values above the diagonal are for castrated male and below the diagonal are for intact males) ( $N=150$ castrated male; $N=120$ intact males)

\begin{tabular}{|c|c|c|c|c|c|c|c|c|c|c|}
\hline & BW & BL & CG & WH & CW & PW & FL & HL & RL & EL \\
\hline BW & 1 & $0.79 *$ & $0.90^{*}$ & $0.65^{*}$ & $0.33^{*}$ & $0.73 *$ & $0.35 *$ & $0.31 *$ & $0.39 *$ & $0.03 \mathrm{~ns}$ \\
\hline BL & $0.75^{*}$ & 1 & $0.77 *$ & $0.66^{*}$ & $0.36^{*}$ & $0.71 *$ & $0.34 *$ & $0.27 *$ & $0.48 *$ & $0.12 \mathrm{~ns}$ \\
\hline CG & $0.80 *$ & $0.67 *$ & 1 & $0.64 *$ & $0.18^{*}$ & $0.64 *$ & $0.36^{*}$ & $0.28 *$ & $0.36^{*}$ & $0.04 \mathrm{~ns}$ \\
\hline WH & $0.69 *$ & $0.63 *$ & $0.63 *$ & 1 & $0.17 *$ & $0.59 *$ & $0.22 *$ & $0.25^{*}$ & $0.39 *$ & $0.14 \mathrm{~ns}$ \\
\hline $\mathrm{CW}$ & $0.52 *$ & $0.53 *$ & $0.34 *$ & $0.39 *$ & 1 & $0.41 *$ & $0.10 \mathrm{~ns}$ & $0.10 \mathrm{~ns}$ & $0.42 *$ & $0.13 \mathrm{~ns}$ \\
\hline PW & $0.69 *$ & $0.62 *$ & $0.63 *$ & $0.68 *$ & $0.47 *$ & 1 & $0.30^{*}$ & $0.37 *$ & $0.44 *$ & $0.07 \mathrm{~ns}$ \\
\hline FL & $0.43 *$ & $0.35^{*}$ & $0.38 *$ & $0.29 *$ & $0.39 *$ & $0.36^{*}$ & 1 & $0.31 *$ & $0.27 *$ & $0.04 \mathrm{~ns}$ \\
\hline RL & $0.43 *$ & $0.45^{*}$ & $0.51 *$ & $0.39 *$ & $0.44 *$ & $0.39^{*}$ & $0.32 *$ & $0.04 \mathrm{~ns}$ & 1 & $0.19 *$ \\
\hline EL & $0.42 *$ & $0.26^{*}$ & $0.32 *$ & $0.13 \mathrm{~ns}$ & $0.21 *$ & $0.14 \mathrm{~ns}$ & $0.15 \mathrm{~ns}$ & $0.24 \mathrm{~ns}$ & $0.24 *$ & 1 \\
\hline $\mathrm{SC}$ & $0.39 *$ & $0.29 *$ & $0.32 *$ & $0.33 *$ & $0.29 *$ & $0.34 *$ & $0.17 *$ & $0.26^{*}$ & $0.24 *$ & $0.11 \mathrm{~ns}$ \\
\hline
\end{tabular}

$\mathrm{BW}=$ Body weight, $\mathrm{BL}=$ Body length, $\mathrm{CG}=$ Chest girth, $\mathrm{HW}=$ Height at whither; $\mathrm{CW}=$ chest width; $\mathrm{PW}=\mathrm{Pelvic}$ width, $\mathrm{FL}=$ face length, $\mathrm{HL}=$ horn length $\mathrm{RL}=$ Rump length; $\mathrm{EL}=$ Ear length; $\mathrm{SC}=$ Scrotal circumference, * Correlation is significant at the $<0.05$, ns $=$ Correlation is not significant at the $P<0.05$, $\mathrm{N}=$ number of animals.

\subsection{Live Body Weight and Linear Body Measurements}

The least squares means of body weight and linear body measurements of indigenous goat found in the study area by district, sex, age and sex by age group interaction are presented in Table 4. Intact and castrated male goat separately used for this analysis.

District effect: in this current study body weight and some of the linear body measurements were significantly affected by the district $(P<0.05)$ except live body weight, wither height, face length, horn length, rump length and scrotal circumference $(P>0.05)$. The results of this study exposed that chest girth measurement was higher for Ancher than Gemechis districts, but body length measurements were higher for Gemechis than Ancher districts. In agreement with current study, [32] reported that district had no effect $(P>0.05)$ on body weight, wither height, and scrotal circumference across studied districts. The correspondence in body weight between goats of different district could be explained by there is no any variation of the management system in the study area.

Sex effects: live body weight and all the linear body measurements were significantly affected by sex groups $(P<0.05)$. The current study Similar with the reports of [3] and [17] whose reported that the sex of the goat had significant effect $(P<0.05)$ on the live body weight and all linear measurements. The mean of BW BL CG WH CW PW FL HL RL EL intact male are $38.1 \pm 0.7,65.2 \pm 0.63$, $74.0 \pm 0.70, \quad 69.0 \pm 0.48, \quad 15.0 \pm 0.12, \quad 15 . \pm 0.14, \quad 19.8 \pm 0.18$, $16.0 \pm 0.56, \quad 16.0 \pm 0.23, \quad 14.4 \pm 0.14, \quad$ respectively. The corresponding values for the female goat were $32.0 \pm 0.22$, $62.0 \pm 0.20, \quad 70.0 \pm 0.22, \quad 64.7 \pm 0.15, \quad 14.2 \pm 0.04, \quad 13.8 \pm 0.04$, $19.0 \pm 0.06,12.0 \pm 0.23,15.0 \pm 0.07,14.1 \pm 0.04$, respectively. Similarly, the present finding higher than previous report of [9] reported that Bale zone of Sinan district intact male and female body weight were $27.5 \mathrm{~kg}$ and $24.4 \mathrm{~kg}$, respectively. However weight of female $32.0 \mathrm{~kg}$ obtained from this study was slightly higher than the value $(31.44 \mathrm{~kg})$ reported for Kaftat and Setit Humera for Begait female goat [17] and [3] reported $31.09 \mathrm{~kg}$ for Shabelle zone female goat but significantly higher than the value for Nuer goat with the value of $19.86 \mathrm{~kg}$ [32] and Arsi-Bale goat with values of $24.4 \mathrm{~kg}$ [9]. In this study body weight and other quantitative traits of castrated male goat higher than female and intact male with the values of $44.4 \pm 0.42,69.6 \pm 0.37,78.9 \pm 0.42$, $72.9 \pm 0.29, \quad 15.1 \pm 0.07, \quad 16.4 \pm 0.08, \quad 20.5 \pm 0.12, \quad 18.1 \pm 0.44$, $15.8 \pm 0.14, \quad 14.7 \pm 0.08$, respectively due to high feed conversion and farmer give high management for castrated male goat than intact male and female goats in both districts.

Age effect: in the present study, age is observed to have effect on body weight and body linear measurements parameters in indigenous goat breed. The linear body measurements increased as animal advances with age 1PPI to 4PPI. The increase in body weight was high between 1PPI, 2PPI and 3PPI whereas the increasing rate was at decreasing rate from 3PPI to 4PPI. The rate of increase in body weight was minimal as the indigenous goat advances in age and recognized to the attainment of mature weight at later age. The body weight of goats at 1PPI to 4PPI was $33.3 \mathrm{~kg}, 36.9$ $\mathrm{kg}, 40.5$ and $42.0 \mathrm{~kg}$, which is greater than $24.13 \mathrm{~kg}, 25.51$ 
$\mathrm{kg}, 25.11$ and $25.57 \mathrm{~kg}$ reported for Arsi-Bale goat types in Sinan district with IPPI to 4PPI, respectively. The present study of body weight at 3PPI with the value of $40.5 \mathrm{~kg}$ was slightly higher than the report of [17] who reported that the body weight at age 3PPI was $40.29 \mathrm{~kg}$ for Begait goat But body weight at the age of 4PPI with the value of $42.0 \mathrm{~kg}$ was lower than the report of [17] who reported that body weight at age 4PPI was $45.63 \mathrm{~kg}$ for the Begait goat.

Sex by age group: the interaction effect of age by sex is significantly $(P<0.05)$ for body weight and most of linear body measurements except chest width, face length, rump length, ear length implying that these parameters were not affected by the sex-age interaction effect in this particular study $(P>0.05)$. In contrary to this, [32] reported that the interaction of sex and age group was significant $(P<0.05)$ for live body weight and all linear body measurement except scrotal circumference which not significant $(P>0.05)$ for Neur goat. Also similar with the reports of [17] and [3] whose reported that the interaction between sex and age group significantly $(P<0.05)$ influenced live body weight and all linear body measurement. The value of live body weight for intact and castrate male was increased as dentition class increased from age group 1PPI to 3PPI and the 4PPI not different with 3PPI. However, in case of females still increases up to 4PPI. The value of body weight for intact male goat in age group 1PPI, 2PPI, 3PPI and 4PPI were 34.3 $\mathrm{kg}, 36.5 \mathrm{~kg}, 40.6 \mathrm{~kg}$ and $40.8 \mathrm{~kg}$, respectively and the values for female in the same age groups were $28.5 \mathrm{~kg}, 30.5 \mathrm{~kg}$, 32.4 and $36.6 \mathrm{~kg}$, respectively. The present finding body weight of the intact male and female for all age group1PPI, 2PPI, 3PPI and 4PPI was higher than previous report of [12] reported that body weight of intact male and female $24.6 \mathrm{~kg}$, $29.5 \mathrm{~kg}, 37.5 \mathrm{~kg}, 40.7 \mathrm{~kg}$ and $21.6,25.2,27$ and $30.3 \mathrm{~kg}$, respectively. The body weight of the castrated male at age group of 1PPI, 2PPI, 3PPI and 4PPI with the value $37.0 \mathrm{~kg}$, $43.7 \mathrm{~kg}$, and 48.5 and $48.6 \mathrm{~kg}$ was higher than the body weight of intact male and female goat in present study. Higher body weight of castrated males greater than that of intact males and female at all ages is due to management is higher by farmer during feeding for good body conformation. In all age groups and measurements, male goats performed greater than female goats. This finding is in agreed with short-eared Somali goats and Hararghe Highland goats, where values for male goats were found greater than their female counter parts in all age group and all measurements [18-25]. Similarly, with the Bageit goats which was conducted in Kafta and Setit Humera and Neur goats which was conducted in Jikawo and Lare, where value for intact male goat were found higher than their female corresponding item in all age group and all measurements [17-32].

Table 4. Least squares means (LSM) \pm standard errors (SE) for fixed effects of sex, age group, location on body weight (kg) and body measurements (cm) for indigenous goats in study area.

\begin{tabular}{|c|c|c|c|c|c|c|c|}
\hline \multirow{2}{*}{ Effect level } & \multirow{2}{*}{$\mathbf{N}$} & BW (870) & BL (870) & CG (870) & WH (870) & CW (870) & PW (870) \\
\hline & & $\mathbf{L S M} \pm \mathbf{S E}$ & $\mathbf{L S M} \pm \mathbf{S E}$ & $\mathbf{L S M} \pm \mathbf{S E}$ & $\mathbf{L S M} \pm \mathbf{S E}$ & $\mathbf{L S M} \pm \mathbf{S E}$ & $\mathbf{L S M} \pm \mathbf{S E}$ \\
\hline \multirow{4}{*}{$\begin{array}{l}\text { Overall } \\
\mathrm{CV} \\
\mathrm{R} 2 \\
\text { Districts }\end{array}$} & 870 & $38.2 \pm 0.26$ & $65.5 \pm 0.2$ & $74.4 \pm 0.23$ & $68.8 \pm 0.16$ & $14.8 \pm 0.04$ & $15.2 \pm 0.05$ \\
\hline & 870 & 0.60 & 6.86 & 6.75 & 5.01 & 5.63 & 6.50 \\
\hline & \multirow[t]{2}{*}{870} & 13.76 & 0.49 & 0.52 & 0.53 & 0.43 & 0.59 \\
\hline & & NS & $*$ & $*$ & NS & * & * \\
\hline Ancher & 435 & $37.8 \pm 0.35$ & $64.6 \pm 0.32$ & $75.5 \pm 0.35^{\mathrm{a}}$ & $68.8 \pm 0.24$ & $14.2 \pm 0.06^{\mathrm{a}}$ & $15.0 \pm 0.07^{\mathrm{a}}$ \\
\hline Gemechis & 435 & $38.5 \pm 0.36$ & $66.3 \pm 0.32$ & $73.2 \pm 0.36^{b}$ & $68.9 \pm 0.25$ & $15.3 \pm 0.06^{\mathrm{b}}$ & $15.30 \pm 0.07^{b}$ \\
\hline Sex & & $*$ & $*$ & $*$ & $*$ & $*$ & $*$ \\
\hline Intact male & 120 & $38.1 \pm 0.70^{\mathrm{b}}$ & $65.2 \pm 0.63^{\mathrm{b}}$ & $74.0 \pm 0.70^{\mathrm{b}}$ & $69.0 \pm 0.48^{\mathrm{b}}$ & $15.0 \pm 0.12^{\mathrm{a}}$ & $15.2 \pm 0.14^{\mathrm{b}}$ \\
\hline Female & 600 & $32.0 \pm 0.22^{\mathrm{c}}$ & $61.6 \pm 0.20^{\mathrm{c}}$ & $70.0 \pm 0.22^{\mathrm{c}}$ & $64.7 \pm 0.15^{c}$ & $14.2 \pm 0.04^{b}$ & $13.8 \pm 0.04^{\mathrm{c}}$ \\
\hline Castrate male & 150 & $44.4 \pm 0.42^{\mathrm{a}}$ & $69.6 \pm 0.37^{\mathrm{a}}$ & $78.9 \pm 0.42^{\mathrm{a}}$ & $72.9 \pm 0.29^{\mathrm{a}}$ & $15.1 \pm 0.07^{\mathrm{a}}$ & $16.4 \pm 0.08^{\mathrm{a}}$ \\
\hline Age group & & $*$ & $*$ & $*$ & $*$ & $*$ & $*$ \\
\hline 1PPI & 201 & $33.3 \pm 0.40^{\mathrm{c}}$ & $61.3 \pm 0.36^{\mathrm{c}}$ & $69.6 \pm 0.40^{\mathrm{c}}$ & $66.6 \pm 0.28^{c}$ & $14.2 \pm 0.07^{\mathrm{d}}$ & $14.4 \pm 0.08^{\mathrm{c}}$ \\
\hline 2PPI & 232 & $36.9 \pm 0.42^{b}$ & $64.1 \pm 0.38^{b}$ & $73.1 \pm 0.42^{b}$ & $68.4 \pm 0.29^{b}$ & $14.5 \pm 0.07^{\mathrm{c}}$ & $15.0 \pm 0.08^{\mathrm{b}}$ \\
\hline 3PPI & 168 & $40.5 \pm 0.62^{a}$ & $67.4 \pm 0.56^{\mathrm{a}}$ & $76.4 \pm 0.62^{a}$ & $69.7 \pm 0.43^{\mathrm{a}}$ & $15.0 \pm 0.10^{\mathrm{b}}$ & $15.6 \pm 0.12^{\mathrm{a}}$ \\
\hline $4 \mathrm{PPI}$ & 269 & $42.0 \pm 0.74^{\mathrm{a}}$ & $69.0 \pm 0.67^{\mathrm{a}}$ & $78.0 \pm 0.74^{\mathrm{a}}$ & $70.9 \pm 0.51^{\mathrm{a}}$ & $15.3 \pm 0.12^{\mathrm{a}}$ & $15.6 \pm 0.14^{\mathrm{a}}$ \\
\hline Sex*Age & & $*$ & $*$ & $*$ & $*$ & NS & * \\
\hline Intact, 1PPI & 79 & $34.3 \pm 0.55^{\mathrm{f}}$ & $61.3 \pm 0.49^{\mathrm{e}}$ & $70.0 \pm 0.55^{\mathrm{f}}$ & $68.0 \pm 0.38^{\mathrm{fc}}$ & $14.5 \pm 0.09$ & $14.9 \pm 0.11^{\mathrm{d}}$ \\
\hline Intact, 2PPI & 26 & $36.5 \pm 0.96^{\mathrm{efc}}$ & $63.5 \pm 0.86^{\mathrm{d}}$ & $72.7 \pm 0.96^{\text {bdf }}$ & $68.5 \pm 0.66^{\mathrm{df}}$ & $14.4 \pm 0.16$ & $15.0 \pm 0.19^{d}$ \\
\hline Intact, 3PPI & 9 & $40.6 \pm 1.65^{\mathrm{d}}$ & $67.8 \pm 1.48^{\mathrm{bc}}$ & $76.9 \pm 1.66^{\mathrm{c}}$ & $69.1 \pm 1.14^{\mathrm{df}}$ & $15.3 \pm 0.28$ & $15.9 \pm 0.32^{\mathrm{bc}}$ \\
\hline Intact, 4PPI & 6 & $40.8 \pm 1.99^{d}$ & $68.0 \pm 1.78^{\mathrm{bc}}$ & $76.7 \pm 1.99^{\mathrm{ce}}$ & $70.3 \pm 1.37^{\mathrm{bcd}}$ & $15.7 \pm 0.33$ & $15.3 \pm 0.38^{\mathrm{cd}}$ \\
\hline Female, 1PPI & 94 & $28.5 \pm 0.52^{\mathrm{i}}$ & $58.5 \pm 0.46^{\mathrm{g}}$ & $67.4 \pm 0.52^{\mathrm{h}}$ & $62.2 \pm 0.36^{\mathrm{i}}$ & $13.6 \pm 0.09$ & $13.2 \pm 0.10^{\mathrm{h}}$ \\
\hline Female, 2PPI & 156 & $30.5 \pm 0.43^{h}$ & $60.4 \pm 0.38^{\mathrm{f}}$ & $67.9 \pm 0.43^{\mathrm{h}}$ & $64.4 \pm 0.29^{\mathrm{h}}$ & $14.0 \pm 0.07$ & $14.7 \pm 0.08^{\mathrm{g}}$ \\
\hline Female, 3PPI & 114 & $32.4 \pm 0.46^{\mathrm{g}}$ & $62.1 \pm 0.41^{\mathrm{ed}}$ & $70.4 \pm 0.46^{\mathrm{gf}}$ & $65.2 \pm 0.32^{\mathrm{g}}$ & $14.5 \pm 0.08$ & $13.9 \pm 0.09^{\mathrm{f}}$ \\
\hline Female, 4PPI & 236 & $36.6 \pm 0.34^{\mathrm{c}}$ & $65.3 \pm 0.30^{c}$ & $74.2 \pm 0.34^{\mathrm{cd}}$ & $67.2 \pm 0.23^{\mathrm{def}}$ & $14.7 \pm 0.06$ & $14.4 \pm 0.07^{\mathrm{e}}$ \\
\hline Castrate, 1PPI & 28 & $37.0 \pm 0.95^{\mathrm{cd}}$ & $64.0 \pm 0.85^{\mathrm{d}}$ & $71.5 \pm 0.95^{\mathrm{f}}$ & $69.5 \pm 0.66^{\mathrm{de}}$ & $14.4 \pm 0.16$ & $15.2 \pm 0.18^{\mathrm{cd}}$ \\
\hline Castrate, 2PPI & 50 & $43.7 \pm 0.70^{\text {bd }}$ & $68.4 \pm 0.62^{\mathrm{b}}$ & $78.8 \pm 0.70^{\mathrm{bc}}$ & $72.2 \pm 0.48^{\mathrm{b}}$ & $15.0 \pm 0.12$ & $16.3 \pm 0.13^{\mathrm{b}}$ \\
\hline Castrate, 3PPI & 45 & $48.5 \pm 0.73^{\mathrm{a}}$ & $72.4 \pm 0.65^{\mathrm{a}}$ & $82.2 \pm 0.73^{\mathrm{a}}$ & $74.9 \pm 0.50^{\mathrm{a}}$ & $15.3 \pm 0.12$ & $17.0 \pm 0.14^{\mathrm{a}}$ \\
\hline Castrate, 4PPI & 27 & $48.6 \pm 0.95^{\mathrm{a}}$ & $73.6 \pm 0.85^{\mathrm{a}}$ & $83.1 \pm 0.95^{\mathrm{a}}$ & $75.2 \pm 0.66^{\mathrm{a}}$ & $15.6 \pm 0.16$ & $17.0 \pm 0.18^{\mathrm{a}}$ \\
\hline
\end{tabular}

a,b,c,d,e,f,g,h,i means with different superscripts within the same column and class are significantly different $(P<0.05)$; NS=Non significant $(P>0.05)$; ${ }^{\text {significant at }}$ $(P<0.05)$; $\mathrm{Na}=$ not applicable; $\mathrm{BW}=$ Body weight, $\mathrm{BL}=$ Body length, $\mathrm{CG}=$ Chest girth, $\mathrm{HW}=$ Height at whither; $\mathrm{CW}=$ chest width; $\mathrm{PW}=\mathrm{Pelvic}$ width; $1 \mathrm{PPI}, 2 \mathrm{PPI}$, $3 \mathrm{PPI}$ and $4 \mathrm{PPI}=1,2,3$ and 4 pair of permanent incisors, respectively. 
Table 5. Least squares means (LSM) $\pm(S E)$ standard errors for fixed effects of sex, age group, location on body weight ( $\mathrm{kg}$ ) and body measurements (cm) for indigenous goats in study area.

\begin{tabular}{|c|c|c|c|c|c|c|}
\hline \multirow{2}{*}{ Effect level } & & \multirow{2}{*}{$\begin{array}{l}\text { FL (870) } \\
\operatorname{LSM} \pm \text { SE }\end{array}$} & \multirow{2}{*}{$\begin{array}{l}\text { HL (461) } \\
\operatorname{LSM} \pm \text { SE }\end{array}$} & \multirow{2}{*}{$\begin{array}{l}\mathrm{RL}(870) \\
\mathrm{LSM} \pm \mathrm{SE}\end{array}$} & \multirow{2}{*}{$\begin{array}{l}\text { EL (870) } \\
\operatorname{LSM} \pm \text { SE }\end{array}$} & \multirow{2}{*}{$\begin{array}{l}\text { SC (120) } \\
\mathrm{LSM} \pm \mathrm{SE}\end{array}$} \\
\hline & & & & & & \\
\hline Overall & 870 & $19.8 \pm 0.05$ & $15.2 \pm 0.21$ & $15.5 \pm 0.07$ & $14.4 \pm 0.03$ & $25.6 \pm 0.15$ \\
\hline CV & 870 & 6.55 & 24.59 & 10.62 & 0.71 & 6.30 \\
\hline R2 & 870 & 0.32 & 0.47 & 0.38 & 0.16 & 0.21 \\
\hline District & & NS & NS & NS & $*$ & NS \\
\hline Ancher & 435 & $19.8 \pm 0.09$ & $15.3 \pm 0.29$ & $15.3 \pm 0.12$ & $14.3 \pm 0.10^{\mathrm{a}}$ & $25.3 \pm 0.36$ \\
\hline Gemechis & 435 & $19.8 \pm 0.09$ & $15.1 \pm 0.39$ & $15.6 \pm 0.12$ & $14.5 \pm 0.10^{\mathrm{b}}$ & $25.9 \pm 0.38$ \\
\hline Sex & & $*$ & $*$ & $*$ & $*$ & \\
\hline Intact male & 120 & $19.8 \pm 0.18^{b}$ & $15.5 \pm 0.56^{\mathrm{b}}$ & $15.6 \pm 0.23^{\mathrm{a}}$ & $14.4 \pm 0.14^{\mathrm{ab}}$ & $25.58 \pm 0.26^{\mathrm{a}}$ \\
\hline Female & 600 & $19.0 \pm 0.06^{\mathrm{c}}$ & $12.0 \pm 0.23^{\mathrm{c}}$ & $15.0 \pm 0.07^{\mathrm{b}}$ & $14.1 \pm 0.04^{\mathrm{b}}$ & - \\
\hline Castrate male & 150 & $20.5 \pm 0.12^{\mathrm{a}}$ & $18.1 \pm 0.44^{\mathrm{a}}$ & $15.8 \pm 0.14^{\mathrm{a}}$ & $14.7 \pm 0.08^{\mathrm{a}}$ & - \\
\hline Age & & $*$ & $*$ & $*$ & $*$ & * \\
\hline 1PPI & 201 & $18.8 \pm 0.11^{\mathrm{d}}$ & $13.3 \pm 0.45^{\mathrm{b}}$ & $14.0 \pm 0.13^{\mathrm{c}}$ & $14.0 \pm 0.08^{b}$ & $24.4 \pm 0.19^{\mathrm{a}}$ \\
\hline 2PPI & 232 & $19.4 \pm 0.11^{\mathrm{c}}$ & $15.9 \pm 0.43^{\mathrm{a}}$ & $14.6 \pm 0.14^{b}$ & $14.4 \pm 0.08^{\mathrm{a}}$ & $25.1 \pm 0.42^{\mathrm{a}}$ \\
\hline 3PPI & 168 & $20.2 \pm 0.16 \mathrm{~b}$ & $15.0 \pm 0.53^{\mathrm{a}}$ & $16.3 \pm 0.21^{\mathrm{a}}$ & $14.5 \pm 0.12^{\mathrm{a}}$ & $25.2 \pm 0.63^{\mathrm{a}}$ \\
\hline 4PPI & 269 & $20.7 \pm 0.19^{\mathrm{a}}$ & $16.5 \pm 0.56^{\mathrm{a}}$ & $16.8 \pm 0.25^{\mathrm{a}}$ & $14.6 \pm 0.15^{\mathrm{a}}$ & $27.7 \pm 0.71^{\mathrm{a}}$ \\
\hline Sex*Age & & NS & $*$ & NS & NS & $*$ \\
\hline Intact, 1PPI & 79 & $18.8 \pm 0.14$ & $14.6 \pm 0.71^{\mathrm{c}}$ & $14.3 \pm 0.18$ & $13.9 \pm 0.11$ & $24.4 \pm 0.19^{c}$ \\
\hline Intact, 2PPI & 26 & $19.1 \pm 0.25$ & $17.9 \pm 0.88^{b}$ & $14.8 \pm 0.32$ & $14.3 \pm 0.19$ & $25.1 \pm 0.42^{b}$ \\
\hline Intact, 3PPI & 9 & $20.5 \pm 0.43$ & $13.5 \pm 1.30^{\mathrm{c}}$ & $16.3 \pm 0.55$ & $14.4 \pm 0.32$ & $25.2 \pm 0.63^{\mathrm{b}}$ \\
\hline Intact, 4PPI & 6 & $21.0 \pm 0.52$ & $16.3 \pm 1.40^{\mathrm{bc}}$ & $16.8 \pm 0.66$ & $14.8 \pm 0.39$ & $27.7 \pm 0.71^{\mathrm{a}}$ \\
\hline Female, 1PPI & 94 & $18.1 \pm 0.14$ & $10.9 \pm 0.48^{\mathrm{d}}$ & $13.6 \pm 0.17$ & $13.8 \pm 0.10$ & - \\
\hline Female, 2PPI & 156 & $18.6 \pm 0.11$ & $11.8 \pm 0.49^{\mathrm{d}}$ & $14.0 \pm 0.14$ & $14.1 \pm 0.08$ & - \\
\hline Female, 3PPI & 114 & $19.4 \pm 0.12$ & $11.8 \pm 0.41^{\mathrm{d}}$ & $16.1 \pm 0.15$ & $14.2 \pm 0.09$ & - \\
\hline Female, 4PPI & 236 & $20.0 \pm 0.09$ & $13.6 \pm 0.35^{\mathrm{c}}$ & $16.2 \pm 0.11$ & $14.4 \pm 0.07$ & - \\
\hline Castrate, 1PPI & 28 & $19.5 \pm 0.25$ & $14.5 \pm 1.01^{\mathrm{bc}}$ & $14.1 \pm 0.32$ & $14.4 \pm 0.19$ & - \\
\hline Castrate, 2PPI & 50 & $20.4 \pm 0.18$ & $18.1 \pm 0.69^{\mathrm{ab}}$ & $15.1 \pm 0.23$ & $14.8 \pm 0.14$ & - \\
\hline Castrate, 3PPI & 45 & $20.8 \pm 0.19$ & $19.9 \pm 0.81^{\mathrm{ab}}$ & $16.5 \pm 0.24$ & $14.9 \pm 0.14$ & - \\
\hline Castrate, 4PPI & 27 & $21.2 \pm 0.25$ & $19.7 \pm 0.83^{\mathrm{ab}}$ & $17.5 \pm 0.31$ & $14.6 \pm 0.19$ & - \\
\hline
\end{tabular}

a,b,c,d.e,f,g,h,i, means with different superscripts within the same column and class are significantly different $(\mathrm{P}<0.05)$; NS=Non significant $(P>0.05)$; significant at $(P<0.05)$; Na=not applicable; $\mathrm{FL}=$ face length, $\mathrm{HL}=$ horn length $\mathrm{RL}=$ Rump length; $\mathrm{EL}=$ Ear length; $\mathrm{SC}(120)=\mathrm{Scrotal}$ circumference; $1 \mathrm{PPI}, 2 \mathrm{PPI}, 3 \mathrm{PPI}$ and $4 \mathrm{PPI}=1,2,3$ and 4 pair of permanent incisors, respectively.

\subsection{Multiple Regression Analysis}

Multiple regression equations were developed for predicting body weight (BW) from other linear body measurements for Ancher and Gemechis goat population. Stepwise regression was carried out for each sex and pooled age group by entering all the above traits at a time for intact male and by excluding scrotal circumference for females and castrated male for selection of independent variables. In castrate male, intact male and female goat heart girth was consistently selected and entered into the model in step one procedure of stepwise regression due to its larger contribution to the model than other variables. At second step of stepwise regression, two independent variables were selected to be in the model, at third step 3 independent variables and so on. The number of variables entered in each step, parameter estimates, their contribution in terms of coefficient of determination (R2), C ( $p$ ) statistic, R2 (adjusted R-square), MSE (Mean square of error), Schwarz Bayesian Criteria (SBC) and Alkaike's Information Criteria (AIC) are presented in Table 6, respectively. The coefficient of determination (R2) represents the proportion of the total variability explained by the model. Chest girth was the first variable to explain more variation than other variables in castrate males $(82 \%)$, intact males $(67 \%)$ and females $(57 \%)$ of Ancher and Gemechis goat. Strong relationship between $\mathrm{BW}, \mathrm{CG}, \mathrm{CW}, \mathrm{PW}$ and $\mathrm{EL}$ for castrate male sample population makes it possible to predict the body weight based on these four linear measurements but for field condition simple measurement with maximum of one or two variables is enough to predict the dependent variable. This is because addition of more variable under field condition increases error, and besides, some variables are more affected by the animal posture compared to others, which makes it so difficult to measure such variables accurately. Similarly, Strong relationship between BW CG BL WH FL RL and EL for intact male while CG BL WH CW PW FL HL and EL for female sampled population make it possible to predict body weight based on these measurements. This suggests that combinations of two or more measurements could more accurately predict body weight than chest girth alone. However, under farmers' conditions, body weight estimation using CG for intact male and female alone would be preferable use to combinations with other measurements because of difficulty of proper animal restraint during measurement. Generally chest girth was the first variable to explain more variation than other variables in castrate males $(82 \%)$, intact male $(67 \%)$ and females $(57 \%)$. This point out that those linear measurements could predict more accurately in castrated males compared to females and intact males. The 
small sample size of intact in this study may decrease the accuracy of the result if separate age groups are used. Thus, instead of using separate equation for different age groups, it seems logical to pool age groups for the prediction of body weight for castrate, intact male and female. The best fitted variables were selected using higher value of coefficient of determination R2, adjusted R2 and smaller value of $C(P)$, AIC, R MSE and SBC. The overall equation of pooled age group used prediction body weight for castrated male, intact males and female by using heart girth. $y=-27.71+0.92 \mathrm{CG}$ for castrate $\mathrm{y}=-20.18+0.75 \mathrm{CG}$ for female and $\mathrm{y}=-17.95+0.86 \mathrm{CG}$ for intact male.

Table 6. Multiple linear regression analysis of live body weight on different body measurements for intact male, female and castrated male goat in study area in all age groups.

\begin{tabular}{|c|c|c|c|c|c|c|c|c|c|c|c|c|c|c|c|}
\hline \multirow[b]{2}{*}{ Intact male } & \multirow[t]{2}{*}{$\begin{array}{l}\text { I } \\
(\boldsymbol{\beta 0})\end{array}$} & \multicolumn{8}{|c|}{ Parameters } & \multirow[t]{2}{*}{$\mathbf{R 2}$} & \multirow[t]{2}{*}{$\begin{array}{l}\text { R2 } \\
\text { Adj }\end{array}$} & \multirow[t]{2}{*}{$\begin{array}{l}\mathbf{C} \\
(\mathbf{P}) \\
\end{array}$} & \multirow[t]{2}{*}{ AIC } & \multirow[t]{2}{*}{$\begin{array}{l}\text { Root } \\
\text { MSE }\end{array}$} & \multirow[t]{2}{*}{ SBC } \\
\hline & & $\beta 1$ & $\beta 2$ & $\beta 3$ & $\beta 4$ & $\beta 5$ & $\beta 6$ & $\beta 7$ & $\beta 8$ & & & & & & \\
\hline $\mathrm{CG}$ & -17.95 & 0.86 & & & & & & & & 0.67 & 0.66 & 52.66 & 159.27 & 3.56 & 163.53 \\
\hline CG BL & -33.92 & 0.45 & 0.58 & & & & & & & 0.77 & 0.76 & 22.07 & 139.65 & 3.01 & 146.03 \\
\hline CG BL WH & -43.65 & 0.36 & 0.50 & 0.31 & & & & & & 0.78 & 0.77 & 18.37 & 136.94 & 2.92 & 145.45 \\
\hline CG BL WH FL & -47.36 & 0.34 & 0.47 & 0.30 & 0.37 & & & & & 0.80 & 0.79 & 14.20 & 133.42 & 2.82 & 144.05 \\
\hline CG BL WH FL RL EL & -57.60 & 0.32 & 0.44 & 0.36 & 0.39 & -0.35 & 1.06 & & & 0.83 & 0.81 & 8.47 & 127.56 & 2.65 & 142.45 \\
\hline \multicolumn{16}{|l|}{ Female } \\
\hline CG & -20.18 & 0.75 & & & & & & & & 0.57 & 0.57 & 104.40 & 841.00 & 3.72 & 848.52 \\
\hline CG BL & -28.06 & 0.46 & 0.45 & & & & & & & 0.64 & 0.64 & 40.88 & 788.80 & 3.43 & 800.10 \\
\hline CG BL PW & -33.47 & 0.38 & 0.41 & 0.97 & & & & & & 0.66 & 0.65 & 26.90 & 776.06 & 3.35 & 791.12 \\
\hline CG BL PW WH & -39.77 & 0.34 & 0.38 & 0.21 & 0.83 & & & & & 0.67 & 0.66 & 18.01 & 767.62 & 3.30 & 786.44 \\
\hline CG BL PW WH EL & -54.89 & 0.29 & 0.40 & 0.26 & 0.74 & 1.09 & & & & 0.67 & 0.67 & 12.82 & 762.52 & 3.27 & 785.11 \\
\hline $\begin{array}{l}\text { CG BL PW WH CW EL HL } \\
\text { FL }\end{array}$ & -49.48 & 0.37 & 0.26 & 0.65 & 0.20 & 0.44 & 0.51 & -0.11 & 0.30 & 0.68 & 0.68 & 9.00 & 758.57 & 3.24 & 792.46 \\
\hline \multicolumn{16}{|l|}{ Castrated male } \\
\hline $\mathrm{CG}$ & -27.71 & 0.92 & & & & & & & & 0.82 & 0.82 & 54.45 & 176.00 & 2.97 & 180.76 \\
\hline CG PW & -41.52 & 0.74 & 1.71 & & & & & & & 0.85 & 0.85 & 11.12 & 161.34 & 2.69 & 168.49 \\
\hline CG PW CW & -48.48 & 0.75 & 0.74 & 1.38 & & & & & & 0.87 & 0.86 & 3.46 & 156.80 & 2.60 & 166.32 \\
\hline CG PW CW EL & -46.52 & 0.75 & 0.76 & 1.38 & -0.16 & & & & & 0.87 & 0.87 & 5.00 & 153.62 & 2.53 & 165.53 \\
\hline
\end{tabular}

$\mathrm{CG}=$ chest girth $\mathrm{BL}=$ body length $\mathrm{PW}=$ pelvic width $\mathrm{WH}=$ wither height $\mathrm{CW}=$ chest width $\mathrm{EL}=$ ear length $\mathrm{HL}=$ horn length $\mathrm{FL}=$ face length; $\mathrm{R}^{2}=\mathrm{R}$-square;

$\mathrm{MSE}=$ mean square of error; A. $\mathrm{R}^{2}=$ adjusted R-square; $\mathrm{C}(\mathrm{p})=$ mallows $\mathrm{C}$ parameters; $\mathrm{AIC}=\mathrm{Alkaike}$ 's Information Criteria; $\mathrm{SBC}=\mathrm{Schwarz}$ Bayesian Criteria.

\section{Conclusion and Recommendation}

Correlation between body weight and linear body measurements for female was recorded for body weight and chest girth $(\mathrm{r}=0.76)$ followed by between body weight and body length $(\mathrm{r}=0.75)$, between body weight and wither height $(\mathrm{r}=0.63)$ and between body weight and pelvic width $(\mathrm{r}=0.62)$. Similarly, for intact male goat population correlation between body weight and linear body measurements were observed between chest girth and body weight $(\mathrm{r}=0.80)$ followed by between body weight and body length $(\mathrm{r}=0.75)$, between body weight and wither height $\mathrm{r}=0.69$ and between body weight and pelvic width $(\mathrm{r}=0.69)$ in both study. However for castrated male goat population correlation between body weight and linear body measurements were observed between chest girth and body weight $(\mathrm{r}=0.90)$ followed by between body weight and body length $(\mathrm{r}=0.79)$, between body weight and pelvic width $(\mathrm{r}=0.73)$ and between body weight and wither height $(\mathrm{r}=0.65)$ in both study. In this current study body weight and some of the linear body measurements were significantly affected by the district $(P<0.05)$ except live body weight, wither height, face length, horn length, rump length and scrotal circumference $(P>0.05)$.
Live body weight and all the linear body measurements were significantly affected by sex groups $(P>0.05)$. Age is observed to have effect on body weight and all linear measurements parameters in indigenous goat breed as indicated. Chest girth was the first variable to explain more variation than other variables in castrate males $(82 \%)$, intact male $(67 \%)$ and females $(57 \%)$. The prediction of body weight could be based on regression equation $y=-27.71+0.92 C G$ for castrate $y=-20.18+0.75 C G$ for female and $y=-17.95+0.86 \mathrm{CG}$ for intact male. For any breed improvement program and to maximize the productivity of indigenous goat, characterization of the breed within their environment provides baseline information. Therefore, this preliminary work could be used to support genetic analyses to determine variation between and within these small populations for the future. There was a variation in body weight and in all linear body measurements of in these districts. This might be due to ability to feed conversion and management differences. The result showed presence of good castrate goat potential in the study areas. Therefore castrated male goat has potential for improving income and to increase economy of smallholder farmers in the study areas as well as in the surrounding areas. 


\section{Acknowledgements}

We would like to express our sincere appreciation to districts Administration office and Livestock Development, all staff members for providing the necessary baseline data for this study. We would like to appreciate and acknowledge the farmers who participated on the interview. We would also like to acknowledge the Development Agents in the study Peasant Associations for their critical support in data collection. We would like to Thank Mizan Tepi University to provide fund for this study.

\section{References}

[1] Adeyinke, I. A., and I. D. Mohammed 2006. Relationship of live weight and linear body measurements in two breeds of goats of Nigeria. Journal of animal and veterinary advances 5 (11): 891-893.

[2] Alade, N. K., A. O. Raji and M. A. Atiku 2008. Determination of appropriate model for the estimation of body weight in goats. Department of Animal Science, University of Maiduguri, Maiduguri, Borno State, Nigeria, ARPN Journal of Agricultural and Biological Science. 3 (4).

[3] Alefe, T 2014. Phenotypic characterization of indigenous goat types and their production system in shabelle zone, south eastern Ethiopia. M. Sc. thesis presented to School of Graduate Study of Haramaya University.

[4] Alemayehu Tadesse, Tikabo Gebremariam and S. K. Gangwar 2012. Application of linear body measurements for predicting body weight of Abergelle goat breed in Tigray region, Northern Ethopia. Global journal of bioscience and biotechnology. vol. 1 (2): pp 314-319.

[5] Aschalew Tsegahun., Sisay Lemma., Ameha Sebsibe, Abebe Mekoya. And Zinash Seleshi 2000. National Goat Research Strategies in Ethiopia. P. 1-5. In: Merkel R. C, Girma Abebe and A. L, Goetsch (Eds). The opportunities and Challenges of enhancing goat production in East Africa 10-12 November 2000. Debub University, Awasa, Ethiopia.

[6] Asefa Belete, Kebede and Kefena Effa 2015. Breeding objectives, selection criteria and breeding system of indigenous goat types in Bale zone, Oromia, Ethiopia pp 7-15.

[7] Belete Asefa,Kebede and Kefena Effa 2015. Breeding objectives, selection criteria and breeding system of indigenous goat types in Bale zone, Oromia, Ethiopia pp 7-15.

[8] Belete Assefa 2013. On farm phenotypic characterization of indigenous goat types and their production system in Bale Zone Of Oromia Region, Ethiopia M. Sc. Thesis. pp. 116.

[9] Belete Assefa and Gelana Jeda 2016. Characterization of indigenous goat type using morphological characters and body measurements in Sinana district, Bale zone, Oromia, South East Ethiopia Volume 16. pp11.

[10] Cankaya, S 2008. A comparative study of some estimation methods for parameters and effects of outliers in simple regression model for research on small ruminants Ondokuz Mayis University, Biometry and Genetics Unit, Kurupelit/Samsun,Turey.

[11] CSA (Central Statistics Agency) 2017. Agricultural sample survey, 2017 (2009 E. C). Volume II, Report on livestock and livestock characteristics. Statistical bulletin, 570, April 2013, Addis Ababa, Ethiopia.

[12] Dereje Tsegaye, Berhanu Belay and Aynalem Haile 2013. Morphological Characterization of Indigenous Hararghe Highland Goat Breed in Their Native Environment, West Hararghe, Ethiopia. American-Eurasian J. of Sci. Res. 8 (2): 72-79.

[13] Dhaba Urgessa, Belay Duguma, Solomon Demeke and Taye Tolamariam 2012. Sheep and Goat Production Systems in Ilu Abba Bora Zone of Oromia Regional State, Ethiopia: Feeding and Management Strategies Global Veterinaria 9 (4): pp421429.

[14] FAO (food and agricultural organization) 2011. Draft guidelines on phenotypic characterization of animal genetic resources. Commission on genetic resources for food and agriculture, thirteenth regular session.

[15] FAO (food and agricultural organization) 2012. Phenotypic characterization of animal genetic resources. FAO Animal Production and Health Guidelines No. 11. Rome.

[16] Galal S 2005. Biodiversity in goats. Small Ruminant Research. 60 (1-2): 75-81. Ain Shams University. Cairo, Egypt.

[17] Gebrekiros, H 2014. On-farm phenotypic characterization of begait (barka) goats and their production system in western zone of Tigray, Ethiopia. M. Sc. thesis presented to School of Graduate Study of Haramaya University.

[18] Grum Gebreyesus 2010. Community-Based Participatory Characterization of the short Eared Somali Goat Population around Dire Dawa. An MSc thesis submitted to School of Animal and Range Science, School of Graduate Studies Haramaya University. 129pp.

[19] Gurmessa Umeta, Feyisa Hundesa, Misgana Duguma and Merga Muleta 2011. Analysis of goat production situation at Arsi Negele Woreda, Ethiopia. Journal of Stored Products and Postharvest Research Vol. 2 (8), pp. 156 - 163, Academic Journals. P156-163.

[20] Halima Hassen \& Samer Lababidi \& Barbara Rischkowsky \& Michael Baum \& Markos Tibbo 2012, Molecular characterization of Ethiopian indigenous goat populations. DOI 10.1007/s11250-011-0064-244: pp. 1239-1246.

[21] Hulunim, G 2014. On- Farm Phenotypic Characterization and Performance Evaluation of Bati, Borena and Short Earned Somali Goat Population of Ethiopia. M. Sc. thesis presented to School of Graduate Study of Haramaya University. 141PP.

[22] IBC (Institute of Biodiversity Conservation) 2004. The State of Ethiopia"s Farm animal Genetic Resources: Country Report. A Contribution to the First Report on the State of the World"s Animal Genetic Resources. IBC, May 2004. Addis Ababa, Ethiopia.

[23] Isaac J. L 2005. Potential causes and life-history consequences of sexual size dimorphism in mammals. Mammal Review, 35: $101-115$.

[24] Kurnianto, E., S. Suto po, E. Purbowati, E. T. Setiatin, D. Samsudewa, and T. Permatasari 2013. Multivariate Analysis of Morphological Traits of Local Goats in Central Java, Indonesia. Iranian J. of Applied Anim. Sci., 3 (2): 361-367. 
[25] Mahilet Dawit 2012. Characterization of hararghe highland goat and their production system in eastern hararghe. MSc. Thesis Haramaya University.

[26] Okbeku, M., Yakubu, A., Olusolapeters, S., Ozoje, M. O., Ikeobi, C. O., Adebambo, O. A. and Imumorin, I. G,. 2011. Application of multivariate principal component analysis to morphological characterization of indigenous goats in southern Nigeria. Received July 22, 2011; accepted September 15 .

[27] SAS (Statistical Analysis System) 2003. for windows, release 9.1, 2004. SAS Institute, Inc., Cary, NC, USA.

[28] Semakula, J., Mutetikka, D., Kugonza, R. D. and Mpairewe, D., 2010. Variability in Body Morphometric Measurements and Their Application in Predicting Live Body Weight of Mubende and Small East African Goat Breeds in Uganda. Middle-East Journal of Scientific Research 5 (2): pp98-105.

[29] Solomon Gizaw, Komen, H., Hanote, O., van Arendonk, J. A. M., Kemp, S., Aynalem Haile, Mwai, O. and Tadelle Dessie. 2011. Characterization and conservation of indigenous sheep genetic resources: A practical framework for developing countries. ILRI Research Report No. 27. Nairobi, Kenya, ILRI.

[30] Tatek Woldu a,b, André Markemann, Christoph Reiber,
Philipp. Mutha, Anne Valle Zárate 2016, Optimising contributions of goat farming to household economic success and food security in three production systems in Ethiopia Vol. 117 No. 1 pp 73-85.

[31] Tesfaye Tsegaye 2009. Characterization of goat production systems and on- farm evaluation of the growth performance of grazing goats supplemented with different protein sources in metema woreda, Amhara region, Ethiopia. Msc Thesis Haramaya university. pp108.

[32] Tsigabu Gebereselassie Gezahegn1, Getahun Asebe Gulich, Kefelegn Kebede and Yosef Mekasha 2015. Haramaya University, College of Agriculture and Natural Resource, Ethiopia Phenotypic characterization of goat type in Nuer Zone of Gambella People Regional State, South Western Ethiopia ISSN: 2408-5502 Vol. 3 (5), pp. 164-180.

[33] Wilson, R. T. and J. W. Durkin 1984. Age at permanent incisor eruption in indigenous goats and sheep in semi-arid Africa. Livestock Prod. Sci. 11 (4): 451-455.

[34] Younas, U., Abdullah, M., J. A. Bhatti, T. N. Pasha, Ahmad, N., Nasir, M. and Hussain, A 2013. The Journal of Animal and Plant science. Inter-Relationship of body weight with Linear Body Measurments in Hissardale Sheep at Different stages of life. 